\title{
CRIMEAN ANNEXATION: EUROPEAN UNION SANCTIONS AND RUSSIAN POLICY
}

\author{
Dr. Shaista Shaheen Zafar \\ Assistant Professor \\ Area Study Centre for Europe \\ University of Karachi \\ Karachi-Pakistan \\ shaheenshaista@yahoo.com \\ Humaira Saeed \\ M.Phil Research Scholar \\ Area Study Centre for Europe \\ University of Karachi \\ Karachi-Pakistan \\ humairaiqbal72@hotmail.com
}

\begin{abstract}
The Russian military attack against Ukraine was the most aggressive development in Europe after the Cold War. The EU and its western allies, applied sanctions against Russia, but could not compel Moscow to comply with the Minsk agreement, which not only highlights the weaknesses of the EU'S CFSP owing to the internal friction between those states which have soft stance on Russia and those which have hardline approach against it in the EU process to impose the penalty packages, but also damage credibility of the EU which has discouraged countries seeking EU membership. Russia, which believes that the expansion of the EU and NATO to its vicinity undermines its core security interests, has adopted an aggressive diplomatic policy and engaged itself in international issues to break the containment policy of the west, that gave Russia a leverage to divide western countries on the issue of sanctions posing threat to the fundamental western interest.
\end{abstract}

Keywords: Ukraine, Crimea, Russia, European Union, Sanctions. 


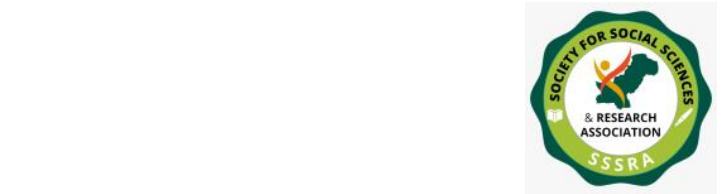

\section{Background of the Study}

Kyiv faced a clear dilemma: either signing the Eurasian Customs Union, or accede to the Association Agreement with the European Union (EU). Being a part of the Association Agreement would mean a strong economic relationship with the west i.e.EU, whereas being a signatory of the Eurasian Customs Union would mean a closer economic integration with Russia and former Soviet Union Member countries, further strengthening its existing historical links (Crozet, \& Hinz, 2020)

The Yanukovych's government's decision not to pursue political and financial unification with the EU, led to widespread protests in Kiev which led to the fall of the Yanukovych regime (Crozet, \& Hinz, 2020) President Yanukovych's deposed administration was deemed pro-Russian and was supported by the majority of Russianspeaking Southern and Eastern Ukraine.

On the other hand, Euromaidan was mostly pro-European or nationalist and had the strongest support in the rest of the country. The EU, including the U.S., supported Euromaidan and the Russian Federation, supported opposite groups, and this political rift took a violent turn (Crozet, \& Hinz, 2020).

Furthermore, the West has made matters worse by promising the accession of Georgia and Ukraine to NATO without granting membership plans or specifying when and under what circumstances this would happen (Larsen, 2021, June 8).

The situation in southeastern Ukraine, especially in Crimea, has been compounded by the seizure of important government properties by separatist and a vote to integrate peninsula into Russia. The next month, Putin initialed a bill that includes the Crimea in the Federation. (Crozet, \& Hinz, 2020). Ukraine in general is important for Kremlin, Crimea is particularly important from the strategic perspective. Its geographical location makes it a "platform for power projection into the Black Sea and beyond." (Lords, 2015).

Russia sees the extension of the European Union through Eastern Partnership initiative and expansion of NATO through military alliances to its borders as an effort to minimize its interest in its vicinity, and therefore a threat to its national security (Kapoor, 2021, March 11).

Putin highlighted above mentioned reservations giving the justification for the annexation of Crimea in his speech to the Russian Upper Chamber on March 18, said: 


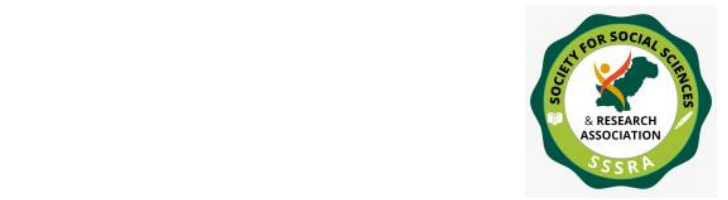

"We have already heard declarations from Kiev about Ukraine soon joining NATO. What would this have meant for Crimea and Sevastopol in the future? It would have meant that NATO's navy would be right there in this city of Russia's military glory, and this would create not an illusory, but a perfectly real threat to the whole of southern Russia." (The Kremlin Moscow, 2014, March 18). Thus, the Putin statement made it clear that the crisis in Ukraine was not only an internal affair, but that Russia was directly involved and protecting its interests in the country (Zafar, 2015).

The color revolutions in its vicinity, and the Euromaidan demonstration against pro-Russian government in Ukraine, also increased Moscow's fear that the same incident might be staged by the White House within Russian soil to carry out its "regime change" policy (Bouchet, 2016).

In order to thwart any possible expansion of Russian influence in the future, the former USSR states in Europe deemed the EU/NATO membership important to them, looking at the additional advantage of achieving economic development with the west (Kapoor, 2021, March 11).

Following the referendum in Crimea, the UNGA adopted resolution 68/262 in March 27,2014. The resolution considered the referendum in Crimea invalid and asked all member states not to acknowledge the Crimean annexation and to stand for Ukraine's territorial integrity. (United Nation General Assembly, 2014, April 1).

\section{Restrictive Measures}

Washington and the European Union together with other allies imposed sanctions against Russia to pressurize it to respect the territorial integrity of Ukraine and protect neighboring countries from any possible Russian aggression in the near future (Veebel, \& Markus, 2016).

Initially, the EU imposed relatively soft series of restrictions on Russia which were first applied on March 17, 2014. It included travel restrictions, asset freezes and prohibitions against dealing with certain persons and companies, including entities established in Crimea and Sevastopol. The list of people and entities sanctioned is under permanent review and is revised frequently by the Council. The EU increased its list of sanctions in October 2020 to 177 individuals and 48 legal persons. The last extension of these measures was in March 2020 until March 6, 2022 (Council of the European Union, 2021, September 15). As part of diplomatic coercion, G7 met in Brussels in June 2014, where Members of the European Union supported the suspension of talks on Russian 


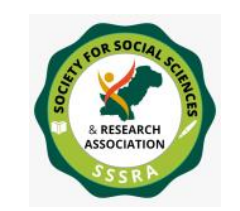

Pak. Journal of Int'L Affairs, Vol 4, Issue 3 (2021)

Crimean Annexation: EU Sanctions ...

membership of the OECD. Two-way visa talks with Russia were also suspended (Veebel, \& Markus, 2016).

In addition to technical and financial support and import-related insurance, the European Union issued a regulation on the importation of products from Crimea and Sevastopol on June 23 2014. These restrictions were extended to cover sectoral investment and export prohibitions. Transport, telecommunications and energy and technological equipment are thus not allowed to be transferred to Sevastopol and Crimea. For associated technical and financial services, the appropriate limits apply. By a broad investment embargo and complemented by limitations on tourism services they were intensified on December18, 2014 (Radio Free Europe: Radio Liberty, 2020, June 18). On June 21, 2021, the Council of the European Union extended these measures until June 23, 2022 (Council of the European Union 2021, September 15).

The EU voted to extend sanctions on Russia after the escalation in military activity in Eastern Ukraine and the downing onJuly17,2014 of Malaysia Airlines' aircraft MH-17, restricting Russia's ability to raise funds on EU financial markets and trade in particular sectors, on July 31. This rule made it unlawful for Russian government securities to be invested or traded with more than $50 \%$ of government interest and beyond 90 days' maturity. The sanctions impacted five Russian state-owned banks (VEB, VTB, Sberbank, Gazprombank and Rosselkhozbank), and financial and its affiliates. Furthermore, the EU has implemented a weapons embargo and associated services on export and imports from Russia. The export prohibition encompasses double-use products and sophisticated petroleum technology. These penalties largely concern stateof-the-art technology for exploring the Arctic shelf and, thus, Russia's future oil returns (Lewis, \& Santa, 2014, July 31).

In March 2015, The Council bound the end of the restrictions to the application of the Minsk deal between Russia and Ukraine (Portela, Pospieszna, Skrzypczyńska, \& Walentek, 2020).

American sanctions against Russia are based on a series of decrees (EO 13660, 13661, 13662 and 13685), which approved in 2014 (Export.Gov, 2019, Aug, 14). The US sanctions are intended to strengthen Russia's political isolation and the cost to Russia, particularly in sectors vital for President Putin and his closest circle. The sanctions in the executive Order targeted various groups and personalities, based on the American President's judgement. Whoever, he believed had a role in undermining Kyiv's security, sovereignty, stability, territorial integrity or had misappropriated the state assets was targeted. The Russian Arms industry and other key sectors of the Russian economy were 


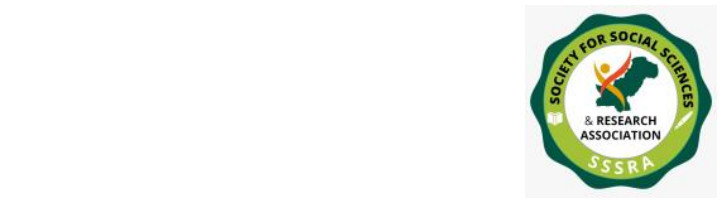

also targeted in the EO, where sanctions were imposed on those government officials and workers who worked in these industries and in the Crimea. Furthermore, US trade, business and investment was also strictly prohibited under these decrees (Congressional Research Service. 2021, June 7). The Trump government continued to impose news anctions on Russia, but at a much slower pace than the former Obama administration, which designated 458 entities and individuals with ties to Russia during the second mandate of Obama versus 273 under Trump (Shin, 2021, January 21). Gas generation and supply are not directly limited by EU sanctions, but Gazprom is targeted by the US. This reflects the dependency of the EU towards Russian gas (Oxenstierna, \& Olsson, 2015). A bill of sanctions called the PEESA (Protecting the Europe Energy Security Act, 2019) was endorsed by the United States in December 2019. The Energy Security Act for Protecting Europe 2019 lays out penalties on foreign individuals, who the President decided where to sell, lease or supply pipeline pipes to Russian pipelines Nord Stream 2 and Turk Stream, or any successor pipelines since December 20, 2019. This bill created a division between the EU and the United States. The European Commission criticized the US sanctions, as did the German administration, which considers them as an unnecessary intervention in Europe and domestic matters (Russell, 2020 March).

\section{Russian Countermeasures}

The Russian retaliation was seen when Russia increased gas cost in Kyiv and reduced its gas supply to Warsaw, Ljubljana, Bucharest, plus, not just the connecting flights of Ukraine airline were banned from Russian airspace, Russia made it clear to those states supporting sanctions against it, that their airlines will also soon get banned from travelling through the Russian airspace. All these were done to weaken the unity of the west against Moscow (Wang, 2015). Along with that, Russia had prepared its own set of sanctions which were imposed on individuals of western governments, according to which they were prohibited from entering Russia, with their accounts and assets frozen. Agricultural, food products and raw materials from the United States, the EU, Canada, Australia, and Norway were banned and this ban was later extended to those nations which were supporting the EU, US led sanctions against Russia (Wang, 2015). Russia raised natural gas prices in Ukraine to put pressure on Ukraine and decreased natural gas exports to Poland, Slovenia and Romania. Connecting flights on Ukraine Airlines were banned from flying through Russian airspace. In addition, Russia also warned that it would also be able to close its airspace to airlines from countries that had taken part in the bans against Russia (Wang, 2015).

The sanctions imposed on Russia gave rise to great patriotism and nationalism in Russia. Instead of stirring up a public reaction against the government, the sanctions enabled the 


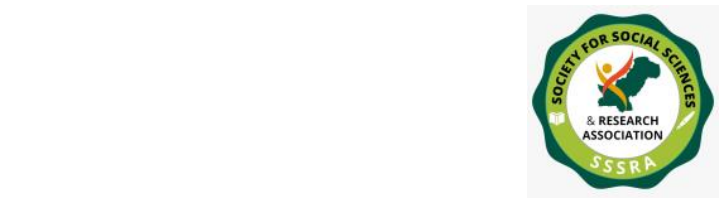

mobilization of its people. As the chairman of the Russian think tank Institute for Contemporary Development stated, "sanctions do not destabilize the Russian regime; on the contrary, they help Putin mobilize nationalism among the political elites" (Wang, 2015). Polls conducted by an independent polling institute, the Levada Center, suggest that Russian opinion remains strongly supportive of the country's actions in Ukraine, despite the sanctions. Support for Vladimir Putin and the annexation of Crimea has remained steady above $80 \%$ since March 2014, while approval ratings for the EU and the US have dropped to $38 \%$ and $30 \%$ respectively. The proportion of respondents who said they were affected by Western sanctions fell from a peak of 35\% in January 2015 to just 19\% in April 2017. In June 2017, more than two-thirds thought Russia should continue its current policies, and only 19\% favoured concessions to lift sanctions (Russell, 2020 March).

Sanctions did not force Russia back to Crimea, instead, Moscow is building a new road and rail bridge that links Crimes with mainland Russia, increasing its military presence on the peninsula to 28,000 soldiers. The conflict intensity in eastern Ukraine has fallen since 2015, but intermittently persists, despite a cessation of shooting. Rebel territories in eastern Ukraine remain outside of Kiev's authority, and there has been no movement towards an integrated political settlement with the rest of the nation. The sanctions did not however persuade Moscow to cease military backing to the rebels or to use their influence on them to halt the struggles (Russell, 2020 March).

In response to the western policy of isolating Russia by means of sanctions, Russia has sought to break out of diplomatic isolation. Despite the continuing mistrust between the two sides, it has strengthened its ties with China by signing multi-billion dollar gas supply agreements via the eastern route (Power of Siberia gas pipeline) in May and November 2014; in August of the same year, the Chinese and Russian armed forces took part side by side in the most significant military exercise in SCO's history. With the support of BRICS countries like China, Russia has managed to evade the exclusion of the G20 summits. In addition, Moscow takes part in the Belt and Road Initiative of China. In 2015, Russia and China agreed to pay some transactions in robles and yuan to reduce their reliance on the US dollar (Russell, 2020 March). The Russo-Sino bond strengthened during president $\mathrm{Xi}$ 's state visit in 2019, where various agreements were signed particularly to strengthen the energy, industrial, agricultural sectors and to increase the commerce by the next five years. A sign of strong commitments and unity was seen when $\mathrm{Xi}$ called Putin as his best friend and both promised to fight against "unilateralism" together (European Parliment, 2020, September, p.15). 


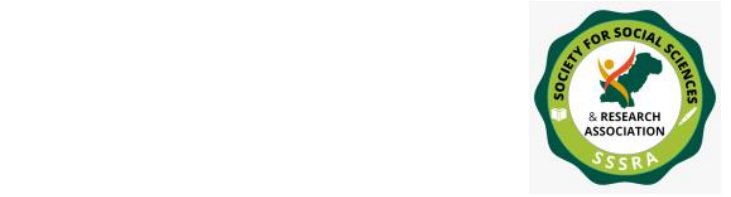

Russia's involvement in the Middle East issues such as Syrian civil war, the Iranian nuclear question and the Libyan crisis is also a part of its broader plan to reassert Russia's great power status breaking the western containment policy, reducing Western pressure that increased following its annexation of Crimea, trying to weaken the cohesion of the West as well as securing a strategic position for itself in the Middle East's emerging geo-economic policy on natural gas and petroleum exports to Europe. Kremlin benefits from the status of a single exporter of natural energy resources to Europe through several underground pipelines. This geopolitical leverage and national interest are at risk as the EU seeks to reduce its excessive reliance on Russia for energy by searching for other sources of energy in the Middle East via the Eastern Mediterranean (European Parliment, 2020, September, p.15). Moscow's intervention in Syria has given it a strategic position in the eastern Mediterranean, and, by doing so, the peripheral players of the region, such as Turkey, Israel, Egypt and the European Union cannot ignore Russia in their projects of search for a new energy "El dorado" (Oligie, 2019).

Russia's involvement in Syria also gave it a strong position in the neighboring countries of Syria,foe example Turkey, where the relations between the two were at an all time low after the shooting down of a Russian plane by Turkish forces in 2015, Turkey now had to re-engaged with Russia. The failed coup attempt against the government of Tayyip Erdogan in 2016 further sped up the cooperation and dialogue between the two countries as was seen when Russia was quick to support the Turkish President's claim of an externally motivated coupd'etat, indicating towards the west (Stronski, 2021, June 28). Energy dependence also plays an important role to stabilize their links. Russia and Turkey signed Turk-Stream agreement in December 2014, and since January 2020 Gazprom started shipping gas through this pipeline, including to Bulgaria and North Macedonia, replacing supplies with the Trans-Balkan pipeline via Ukraine and Romania (Reuters 2020, January 5).

Since 2015, Moscow has supplied military, political and economic aid to the Government of Eastern Libya in Tobruk and the LNA in its fighting against the UNsupported Government of National Accord (GNA) in Tripoli. Pictures released in May 2020 by U.S. Africa Command (AFRICOM) showed the deployment of fighting and intercept aircraft, by Russia, to Libya's Al Khadim and Al Jufra air bases. These Russian activities reveals not only an expansion of Russian air activity, but also of its ground forces, namely the Russian private military company (PMC) Wagner Group (Bermudez, 2020, June 17).

Russia's perceived achievements in Syria have also encouraged other Middle Eastern countries to seek to improve their relations with Moscow. Thus, Russia's stronger 


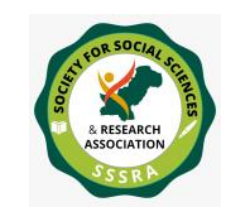

presence in the Middle East and its role in international negotiations on Iranian and Afghan questions as well as its role in organizing a ceasefire between Armenia and Azerbaijan on the contested territory of Nagorno-Karabakh, prompting some observers to speak of "Russian revival" or even to draw parallels with the regional dynamics of the Cold War (Aljazeera, 2020, October 1).

\section{Division amongst EU Member States}

The EU's credibility is undermined when its member states failed to formulate a coherent policy against Russia.France, Germany and Italy are more interested in bilateral relations withRussia.These bonds were built on common economic and energy interests, through which the Member States sought to stimulate their commerce with Russia or to obtain preferential energy prices.Certain CEEC Member States are very sensitive to Moscow's use of energy and prices as policy tools (Cristian, 2016). The Baltic States see Russia as a threat to its security and tend to believe that the US must keep Russia under constant tension (Zafar, 2015).

Energy relations between Germany (FRG) and the Soviet Union have been growing since the mid-1970s. At the end of the Cold War, the FRG was the largest purchaser of Soviet energy resources and the reunified Germany further strengthened its energy partnership with Russia.Immediately after the end of the Cold War, Germany sought closer ties with Russia. It supported the intensification of links between Russia and Western organizations. This approach developed considerably during the chancellorship of Gerhard Schröder, who promoted a key German-Russian organization. One of the key elements of this partnership was to be participation in the gas sector. The Nord Stream 1 (NS1) gas pipeline agreement was approved in 2005. During the grand coalition 2005-2009, the idea of "progress through interdependence" was implemented, and this strategy was maintained during the period 2009-2013, even though Russia had attacked Georgia in 2008. After the annexation of Crimea to Russia, the subsequent years showed that Germany really wanted to pursue its earlier policy towards Russia especially in the gas sector. The German government's resistance to sanctions against Russian oil and gas led some experts to conclude that Germany's dependence on Russian gas had reduced its policy options vis-à-vis Russia. This view was also echoed by US leader Donald Trump, who called Germany a hostage to Russia at the start of the 2018 NATO summit (Ulatowski, 2020).

Germany's reputation has recently been damaged by its strong support for the Nord Stream 2 pipeline project. That support has remained strong, despite the concerns of 


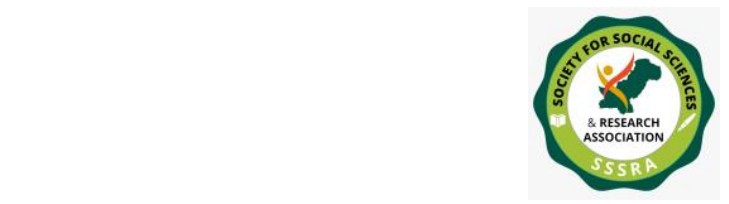

Berlin's accomplices in the EU. Germany benefits economically from the deal, which promises to turn the country into a local oil and gas hub while ensuring inexpensive supply to the German industries. Few other European countries are interested in this project as well.In December 2018, the European Parliament voted massively against Nord Stream 2 as "a political venture that threatens European energy security"and asked to have the project cancelled.In spite of this resistance, the German Chancellor firmly defended the pipeline as a strictly trade agreement (Francis, 2021, January 2). The U.S. Congress and the Senate adopted the National Defense Authorization Act, which authorized the United States to imposesanctions, to derail the construction of the remaining 55 bn $\mathrm{m}^{3} / \mathrm{yr}$ Northern Stream 2 offshore portion of Gazprom, controlled by the Russian state (Francis, 2021, January 2). Critics see that if this project were completed, it would also cause damage to Ukraine by making the country's gas transmission system largely redundant and depriving Kiev of substantial transit incomes (Gugarats, 2021, January 1). Germany has endeavoured to address concerns by ensuring that Poland and Ukraine are not the losers of the pipeline, while Russia has pointed out that Nord Stream 2 could also become a vital hydrogen exchange route with Europe (Francis, 2021, January 2).

France's rapprochement with Russia is very much felt by the other European nations due to the tradition of good relations that exist between the two states. In de Gaulle's period, France depended on ties with Moscow to, among other things, regulate the influence of the United States in Europe, a rationale that has been maintained until recently. France has always considered that European security could not be achieved without a solid anchoring of Russia on the Old Continent. This was once again evident in the wake of the war in Georgia. At the 2008 World Policy Conference, President Sarkozy was clear on this point: "Relations between Russia and the European Union have recently been the subject of a real preliminary decision. I conclude that the EU and Russia must not go their separate ways, which would revive fears of a new division of Europe and dreams of 'another cold conflict'. A new cold war would be a clear mistake (Facon, 2018).

The French policy of the governments Nicolas Hollande and Macron since the annexation of Crimea on Russia can be summed up with the dual formula "negotiation and solidarity".By supporting and enhancing political, monetary and social interaction with Russia, France aspires to safeguard its security, European and transatlantic unanimity, as well as its democratic and liberal principle. Macron's government policy toward Russia established that his government prioritized negotiations over solidarity, for instance, he welcomed Putin to the Palace of Versailles at the beginning of its mandate, led a business delegation to the St. Petersburg International Economic Forum, and 


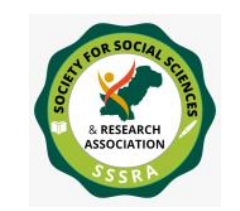

emphasized on numerous occasions the importance of Russia in the resolution of the Syrian crisis and the nuclear crisis in Iran (Heng, 2020, July 9). France along with Germany strongly supported re-established Russia's right to vote in PACE despite strong protests from Ukraine, Poland, the Baltic states and the Britain (Cavegn, 2019, June 25). Above all, Macron would like to visit Russia even during the current pandemic (Heng, 2020, July 9).

In economic fields despite western sanctions and Russian countersanctions the relationship between Russia and France continues. Since 2015, France has been a major foreign investor in Russia and the leading foreign employer. Russia appreciates the contribution made by French businessmen in the Russian financial sector to reduce the effects of Western sanctions upon the Russian economy. The Yamal LNG liquefied natural gas project, in which Total Energies, a French oil and gas multinational company has $20 \%$ share, is exemplary in this respect: it offers up new worldwide opportunities for Russian hydrocarbons while delivering a powerful political message about the possibilities of working in Russia without the US currency (Kastoueva-Jean, 2019, December 9).

In his talk with The Economist in November 2019, Macron reaffirmed his commitment to engage Russia despite the difference. In the interview, he called for a Russia-EU partnership based on a new "trust and security architecture" and cautioned against a "stand-alone option for Russia." (Kastoueva-Jean, 2019, December 9). Macron claimed that western sanctions have failed to put the pressure on Russia, to abandon control of Crimea or to put an end to intervention in Donbass (Deni, 2020, March 27). He also warned that NATO was becoming brain-dead and that "Europe if it can't think of itself as a global power, will disappear, because it will take a hard knock." The French leader's comments about the brain death of NATO created a furor, but he doubled down on them later the same month. "Is our enemy today Russia, as I sometimes hear? Is it China? Is it the goal of NATO to designate them as enemies? I don't believe so. Our common enemy today is terrorism, which has hit each of our countries," Macron said (Radio Free Europe and Radio Free Library 2019, November 28).

Italian Prime Minister Giuseppe Conte, speaking to Parliament in June 2018, expressed his interest in the elimination of certain EU sanctions which have harmed Russian civil society (Radio Free Europe and Radio Free Library, 2018, June 6). In October he visited Russia to strengthen economic relations that have been seriously affected by EU sanctions against Russia and Moscow's repressive actions (Isachenkov, 2018, October 24). The adverse effect of the sanctions on Italy was mentioned by the data provided by Coldiretti, which reported that a 50 percent decline in Italian food 


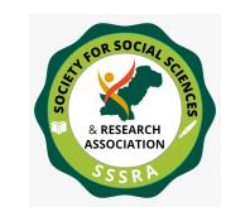

Pak. Journal of Int'L Affairs, Vol 4, Issue 3 (2021)

Crimean Annexation: EU Sanctions ...

exports to Russia was registered over four years, with the Italian north east region being hit the hardest (Maio, 2019, March 11).

However, Italy countered this effect, as Italian companies exported goods to Russia via Serbia or Belorussia and some even delocalizing their production to Russia, thus part of the losses suffered in the first two years of the sanctions were recouped,as was depicted by the increase in trade from 27 billion Euros to 36 billion Euros since 2017. This witnessed further collaboration when Italian companies signed various deals with their Russian counterparts specifically in the field of electric energy, technological development and research (Maio, 2019, March 11).

Spain is part of both the EU and NATO, yet its position on Russia can be presented as "balanced". Russia and Spain are geologically distant from each other and have no significant issues andhave limited monetary relations. Spain gets about $14 \%$ of its oil from Russia but does not use Russian gas. Nor does Madrid see Russia's activities in Ukraine as an immediate threat. It has been reluctant to maintain EU sanctions against Russia, which are hurting the Spanish economy. Some Spanish food exporters have been affected, but wine and olive oil tariffs, for example, have been exempted from Russian counter-sanctions (Dunaev, 2018, March 5). The Russian Foreign Ministry supported Madrid during the Catalan emergency, declaring that it regarded the circumstances as a Spanish affairand expressing the hope that it would be solved in compliance with Spanish law (Dunaev, 2018, March 5).

Bulgaria's monetary and commercial ties with Moscow are limited compared to relations with EU Member States and neighbouring countries. However, Russia has increased its political inflow to Bulgaria through its energy supply imports. With a share of $2.6 \%$ of the total, Russia ranked ninth in Bulgaria's economic sectors in 2013 (Lessenski, 2015). The Bulgarian tourism sector is also increasingly dependent on Russian tourists. In 2013, Russians accounted for $13 \%$ of all accommodation and resort customers. With the onset of the emergency in Ukraine, it is expected in the travel industry that the sanctions against Russia will bring the 2014 summer season to an end (Lessenski, 2015). Boiko Borissov, the Bulgarian prime minister, expressed concern about the disintegration of monetary circumstances at a meeting with the EU commissioner in December 2014. According to the EU statistics office Eurostat, Bulgaria's exports to Russia decreased by 22 percent in August compared to the previous year. (Croft, 2014, December 4).

Beyond the economic links, Bulgaria and Russia also share a great deal of historical, linguistic and cultural commonality (Smilov, \& Andreev, 2018, May 31). 


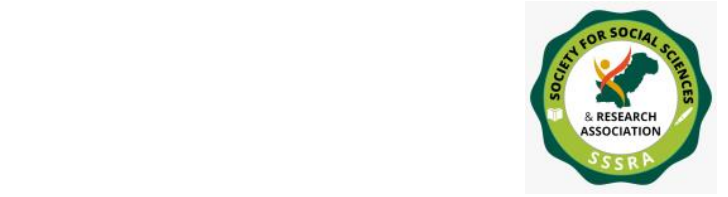

In June 2019, the present improvement of Bulgarian-Russian ties was undoubtedly illustrated by the two high level visits. A Bulgarian parliamentary group led by TzvetaKarayantcheva, Chairman of the National Assembly visited Moscow on 25-26 June 2019. Half a month earlier, from 6 June to 8 June, President Rumen Radev visited Russia to attend International Economic Forum and met with his Russian counterpart Vladimir Putin (China-Cee Institute, 2019, July 9). During meeting with Putin, Bulgarian President highlighted that Bulgaria was an EU Member State and a NATO, but that this did not hinder improving positive ties with the Russian Federation. He also reiterated that Bulgaria and Russia are major energy partners and that this engagement may be increased (China-Cee Institute, 2019, July 9). For the first time, the Speaker of the Bulgarian National Assembly addresses the Russian Parliament and underlined the necessity for expanded energy cooperation (China-Cee Institute. 2019, July 9).

The Joint Action Program on Tourism between the Tourism Ministry of the Republic of Bulgaria and the Economic Development Ministry of the Russian Federation for 20192021 was signed between Bulgaria and Russia in March 2019.It is part of the implementation of the Tourism Cooperation Agreement of May8, 2007 between the two States. It is considered another major milestone in developing the normal strong ties between the two nations (Republic of Bulgaria: Ministry of Tourism, 2019, March 4).

Bulgaria depends almost entirely on the Russian gas supply: 98.3 per cent of its natural gas demand is supplied by Russia through Ukraine (Assenova, 2018, December 6). In October 2019, Bulgaria inaugurated the 11-kilometre gas pipeline connecting its gas transmission network to Turkey in connection with Bulgaria's plans to connect its southern border with Turkey to its western border with Serbia, and provide a link to the Russian-supported TurkStream dual pipeline to Serbia, Hungary and Austria (Tsolova, \& Soldatkin, 2019, October 21).

This whole dynamic of bilateral relations between Bulgaria and Russia demonstrates that Russia is an important partner of Bulgaria, especially in the field of energy, which occupies a leading position in bilateral relations.

Initially, the Visegrad countries, seeing the Ukrainian crisis as a direct threat to the security of their region, agreed on a common position on "tier 1" and "tier 2" sanctions. Later, the Visegrad states adopted separate policies on implementing harsher sanctions against Russia, which divided them (Wallberg, 2015). The dividing lines are formed on assessing Russia's threat, the effectiveness of sanctions and their subsequent application, and the means to pursue national economic interests, especially in the energy sector (Romanowska, 2018, September 24). 


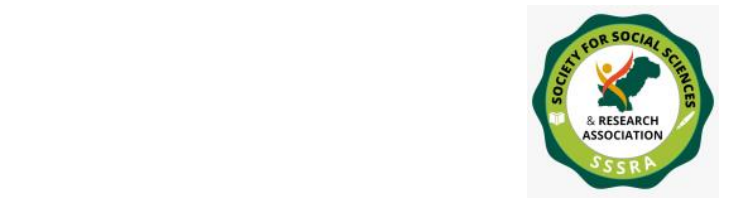

The position of Hungary, the Czech Republic and Slovakia vis-à-vis Russia differs from the tougher position of Poland and the Baltic States, because they see that there is no immediate security threat from Russia (Romanowska, 2018, September 24). Hungary is highly dependent on Russia's energy supply and, because of the political confrontation between Europe and Russia, is facing a precarious situation (Wallberg, 2015). Budapest is lobbying for the removal of monetary and political restrictions on Russia, (Romanowska, 2018, September 24). that prohibit EU companies from granting loans to Russian banks, blocking the Hungarian plan to expand the Paks nuclear power plant (Wallberg, 2015). In an interview with CNBC in 2017, the Hungarian Foreign Minister criticized the EU's policy of sanctions against Russia, challenging their effectiveness in influencing Moscow's policy in Ukraine conflict (Cutmore, \& Reid, 2017, October 4).

The governments of Prague and Bratislava distance themselves from the US decision to arm and strengthen the Ukrainian armed forces and present their position in this regard as realistic, identified with the satisfaction of the financial interests of their nations and citizens (Romanowska, 2018, September 24). Czech President MilošZemanand Prime Minister Andre Babiš expressed their skepticism about the sanctions against Russia. Zeman met with Putin in Sochi in November 2017 (President of Russia, 2017, November 21a). to improve two-way trade, which had increased by 42.9 per cent in January-September (President of Russia, 2017, November 21b). During the same month, the President accompanied by Czech businessmen visited Russia where they signed 13 contracts with their Russian counterparts, worth over 20 billion Czech korunas (around USD 750 million) (International Investment Bank, 2017, November 23).

The issue of companies losing profits due to sanctions is a hot theme in the discussion of Czech public. The Prime Minister Andre Babiš has also followed this pattern and advocated the resumption of economic ties with Russia. He also stressed that, in his view, Crimea would not be returned to Ukraine, although his government does not believe in Russian expansion (Dębiec, 2019, February 10). One of the reasons for Babiš's escape is his strategic coalition with President Zeman, which helps Czech enterprises penetrate the Russian and Chinese economic sectors. Another important fact is that a large portion of the electorate of both the President and the Prime Minister are in favour of co-operation with Russia (Dębiec, 2019, February 10). In short, the political trend swing between multilaterals ( focusing on the demand for an EU cluster approach) and realistic (securing financial interest) position (Forbrig, 2015).

The Slovak Prime Minister Robert Fico (2006-10 and 2012-March 2018) attempted to combine two contradictory political views on the Ukrainian issue. On the 


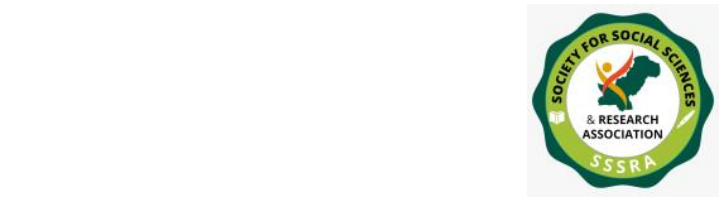

one hand, he supported the process of European integration of Ukraine, and on the other hand he resisted the sanctions of the European Union against Russia and supported logical collaboration with Moscow, including "collision-free relations" between the EU/NATO and Russia. Fico was most openly opposed to economic sanctions on Russia. Commenting on the conclusion of the EU summit in May 2014 that acknowledged preparatory work on targeted measures against Russia, he said that tougher sanctions would be "suicidal" and "nonsensical."

Fico also rejected Slovakia's calls for increased defence spending and compliance with NATO membership obligations, especially considering Russia's military hostility towards Ukraine (Forbrig, 2015).

Cooperation with Moscow is supported by public opinion in Slovakia. A 2017 survey by the International Republican Institute of the United States (IRI) found that 75 per cent of Slovaks agree with closer security collaboration with Russia. Thus, they represent the most pro-Russian attitude. This view is confirmed by a Eurostat survey of the same year, which found that $50 \%$ of Slovaks were in favour of Russia (The Polish Institute of International Affairs, 2019, September 18).

In addition, Slovakia and Russia continue to engage in the energy sector. The impact of Prime Minister Peter's visit to Moscow in February 2020 was the conclusion of two agreements. One was concluded between the Slovak Ministry of Economy and the Russian company Rosatom and the other between TVEL, which is part of Rosatom and the Slovak electricity producer Slovenské Elektrárne. The agreements provide for the transport of nuclear fuel to the thermal power plants in Bohunice and Mochovce for the period 2022-2025, with a possible extension until 2030.During his visit in Moscow, Pellegrini expressing his interest in NS2 gas, offered Russia the possibility of depositing gas. In turn, the Russia assured Slovak suppliers that gas supply would remain regular after 1 January 2020. (The Polish Institute of International Affairs, 2019, September 18).

After the general elections in March 2020, the Pellegrini government, which had sought to strengthen cooperation with Russia, was replaced by the right-wing government of Igor Matovic, which has demonstrated its interest in strengthening its relations with its Euro-Atlantic allies, with an emphasis on Western values and principles rather than economic interest-based realism, which was a central approach to the foreign policy of previous governments.In spite of this western inclination approach Matovic's government signed a secret agreement with Moscow to buy Russia's coronavirus vaccine Sputnik V that was not approved by the EU, (Associated Press, 2021, March 30). and which have 


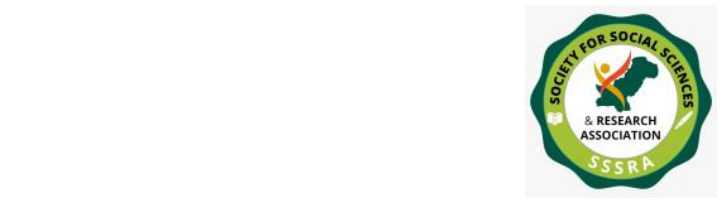

Pak. Journal of Int'L Affairs, Vol 4, Issue 3 (2021)

Crimean Annexation: EU Sanctions ...

been seen by critics in contradiction with Matovic's pro-Western stance (Holroyd, 2021, March 3).

Since the beginning of the Ukraine conflict, thesuccessive Polish governments have been in the vanguard of the promotion of restrictions against Russia, and has always been in favour of extending the package until Russia does not fulfil its Minsk obligations. Prime Minister Donald Tusk (2007-14) criticized the EU for applying the "soft and inconsistent" Russian sanctions, while former Foreign Minister Radoslaw, has criticized restrictions for not being enough. In June 2019, all Polish members of the Parliamentary Assembly of the Council of Europe voted in favour of the continuous suspension of Russia. The Poles have a strong support for Russian sanctions and polls reveal that 68 per cent support their retention and over half support the setting of penalties, while just 7 per cent believe that they are too severe.Another study found that $62 \%$ of Poles support tougher sanctions, whilst only $32 \%$ oppose.

The biggest criticism of the sanctions against Russia was brought up by the commercial elite (Portela, Pospieszna, Skrzypczyńska and Walentek, 2020, Aug 10). Despite sanctions, in May 2021, Russia exported 1.15 billion dollars and imported 492 million dollars from Poland, leading to a positive trade balance of 659 million dollars. Between May 2020 and May 2021, Russia's exports grew by $\$ 678 \mathrm{M}$ or 143 percent, from $\$ 473 \mathrm{M}$ to $\$ 1.15 \mathrm{~B}$, while imports rose by $\$ 209$ million, or 73.7 per cent, from $\$ 283$ million to $\$ 492$ million (The Observatory of Economic Complexity (OEC), 2019).

Exports to Russia from Poland, its dependence on Russian energy imports and the campaigns to establish trade links with Russia have demonstrated Poland's weaknesses with respect to its sanctions requirements (Portela, Pospieszna, Skrzypczyńska and Walentek, 2020, Aug 10).

Austria was highly skeptical about sectoral sanctions against Russia for fear of economic consequences, and was the first state that officially welcomed Putin after the annexation of Crimea. In June 2014, in spite of US and EU criticism, the two countries signed an agreement for the construction of Austria's South Stream section, that would be able to transport Russian gas to central Europe, by bypassing Ukraine via Bulgaria, Serbia, Hungary and Slovenia. (DW News, 2014, June 24). It was a very controversial visit to Austria, but there is still an enormous support for lifting sanctions against Russia as soon as possible. It has shown that, in the future, Russia can exploit the financial and political weaknesses of the EU Member States to create a division in any common European approach. Austria's reluctance towards an assertive European agreement is entirely monetary. Vienna imports about 70 percent of its gas from Russia (Gressel, 2015, 


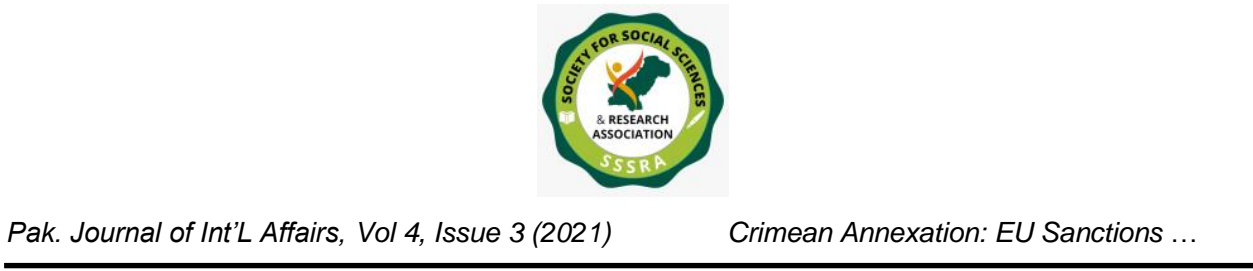

January 21). In June 2018, during the celebrations of the 50th anniversary of Russian gas supply to Austria, Gazprom and OMV Gas Marketing and Trading GmbH extended the long-term contract for gas supply to Austria until December 31, 2040 (Gazprom Export, 2021). Austrian banks and corporations have made massive investments in Russia. Vienna fears a collapse of the Russian market or reprisals that might strike both the banking system and the state (Gressel, 2015, January 21).

Consequently, the fragile economic situation and the current political confusion of Central Europe are considered a possible threat to European unity as regards Russia.

After the annexation of Crimea, Latvia, Estonia and Lithuania, all of which separated from the Soviet Union in 1990-91, called for additional EU sanctions on Moscow (Reuters, 2014, June 21). The most important thing in the minds of the Baltic states, due to the nearness of the border with Russia, is the overflow of conflicts in the Baltic region (Torre, 2019). Especially Estonia and Latvia which have a large Russianspeaking minorities, considered to be fertile ground for future conflicts (Otskivi, 2016). The Baltic States therefore prefer the United States to always maintain pressure on Russia (Zafar 2015). Security concerns in the Baltic States have led Lithuania, Latvia and Estonia to reach the $2 \%$ goal for NATO military spending, whereas the United States has considerably increased its military assistance to the countries. As part of the Foreign Military Financing program, the United States invested \$150 million to develop Baltic defence capabilities and sold defence assets worth about $\$ 456.7$ million (Bergmane, 2020, June 1).

\section{Conclusion}

Russia sees the extension of the European Union through Eastern Partnership initiative and expansion of NATO through military alliances to its borders as an attempt to restrict its activities in its vicinity, and hence a risk to its national security. At the 2007 Munich Conference on Security Policy, Putin described the NATO expansion as a main challenge that undermines mutual confidence. The 2016 Moscow National Security Strategy underscores the threat posed by NATO.The color revolutions that overthrow Russian allies overseas, also incriminated Moscow's concerns that it could set a precedent in Russia. The Euromaidan demonstration, which was considered in Russia as a foreign-funded protest, reinforced its reservations.

When Russia annexed Crimea and destabilized eastern Ukraine, the EU and its western partners applied economic sanctions. In response to the western policy of isolating Russia by means of sanctions, Russia has sought to break out of diplomatic 


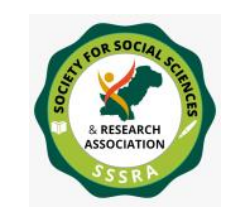

isolationism. Russia's stronger presence in the Middle East, where the western political and energy interests are high, and its role in international negotiations on Iranian and Afghan questions as well as its role in organizing a ceasefire between Armenia and Azerbaijan on the contested territory of Nagorno-Karabakh, encouraging some scholars to talk about "Russian Renaissance " or even to draw parallels with the regional dynamics of the Cold War.

Russia benefited from the fragile economic situation and current political weaknesses of EU Member States, to minimize international pressure on the Ukrainian issue. In this respect, Russia is resorting to economic pressure and the exploitation of energy exports, which are seen as a potential threat to European unity vis-à-vis Russia. The EU is an alliance of 27 sovereign states which have given the Union certain powers, principally linked to economic areas, but have not yet relinquished their sovereignty over defense and foreign policy, particularly where national interests are involved. Thus, the Crimean crisis has highlighted that the EU has failed to address the issue as a union. Initially, the EU reacted strongly to the annexation of Crimea, but the traditionally different attitudes of its Member States towards Russia quickly appeared.

Countries like Bulgaria, Cyprus, Greece, Italy, Slovenia, Portugal and Spain, Hungary and Austria held a mild stance against Moscow and looked for reengaging with Russia due to their strong financial, cultural, religious or energy links. Poland and Baltic states were for severe sanctions against Russia. France and Germany found themselves in between and held a moderate position. Russia, by its flexible policy, like visa-free and unrestricted mobility of people and access to the Russian market has a strong control over its former satellite states. While the objectives of accession to the EU's Eastern Partnership initiative, namely democratization, market reform and the protection of human rights, are a hard prerequisite for partner countries.

The EU does not have a military mussels. The global financial crisis in 2008, and currently the COVID-19 pandemic, further weakened the possibility of the exercise of the military option by EU members as well as undermined the EU's ambitions to reduce its military reliance on the US. The undeclared war between Russia and Ukraine has entered its eighth year in 2021 with no end in sight to a conflict that has shattered the security assumptions of the post-1991 world. Lack of military power has no option left for the EU to apply soft power tools to force Russia to comply Minsk agreement or to cease its military backing to the rebels. But this policy not only has failed in the face of the hard power tools that Russia has applied in Crimea but also discouraged other countries in the region from opting for a European system and relying on the EU. 


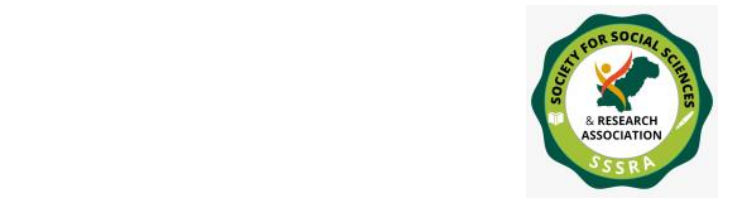

Pak. Journal of Int'L Affairs, Vol 4, Issue 3 (2021)

Crimean Annexation: EU Sanctions ...

\section{References}

Aljazeera (2020, October 1). What has Russia gained from five years of fighting in Syria? Aljazeera. https://www.aljazeera.com/features/2020/10/1/what-has-russia-gained-fromfive-years-of-fighting-in-syria.

Assenova, M. (2018, December 6). The Balkan Gas Hub: A European Gas Trading Platform or South Stream Lite? Eurasia Daily Monitor 15(172).

https://jamestown.org/program/the-balkan-gas-hub-a-european-gas-trading-platform-orsouth-stream-lite/

Associated Press. (2021, March 30). Slovak Premier, Government Resign Over Russian Vaccine Deal. US News. https://www.usnews.com/news/world/articles/2021-0330/slovak-premier-government-resign-over-russian-vaccine-deal.

Bergmane, U (2020, June 1). Fading Russian Influence in the Baltic States. Orbis,64(3). https://www.ncbi.nlm.nih.gov/pmc/articles/PMC7329289/

Bermudez, J. S. (2020, June 17). Moscow's Next Front: Russia's Expanding Military Footprint in Libya. Centre for Strategic and International Studies. https://www.csis.org/analysis/moscows-next-front-russias-expanding-military-footprintlibya.

Bouchet, N. (2016). Russia's militarization of colour revolutions.CSS Policy Perspectives, 4(2). https://css.ethz.ch/content/dam/ethz/special-interest/gess/cis/centerfor-securities-studies/pdfs/PP4-2.pdf

Cavegn, D. (2019,June 25). Estonian PACE representatives vote against restoring Russia voting rights, ERR News https://news.err.ee/955569/estonian-pace-representatives-voteagainst-restoring-russia-voting-rights.

China-Cee Institute. (2019, July 9). Bulgaria and Russia-between traditional friendship, strategic interests and political tensions. https://china-cee.eu/2019/07/09/bulgariaexternal-relations-briefing-bulgaria-and-russia-between-traditional-friendship-strategicinterests-and-political-tensions

Congressional Research Service. (2021, June 7). U.S. Sanctions on Russia: An Overview. In Focus. https://sgp.fas.org/crs/row/IF10779.pdf.

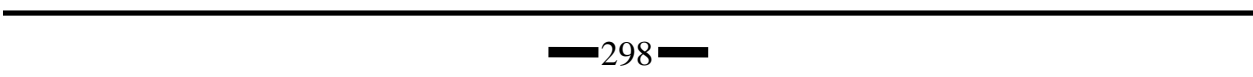




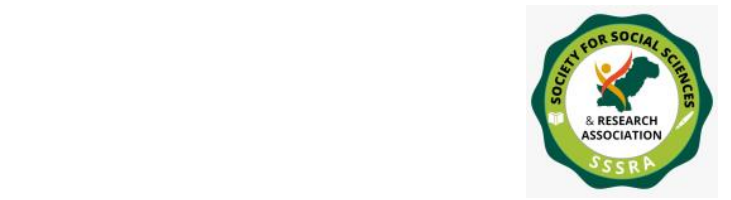

Pak. Journal of Int'L Affairs, Vol 4, Issue 3 (2021)

Crimean Annexation: EU Sanctions ...

Council of the European Union. (2021, September 15). EU restrictive measures in response to the crisis in Ukraine. https://www.consilium.europa.eu/en/policies/sanctions/ukrainecrisis/.

Cristian, N. (2016). The Ukraine crisis and the conflict/cooperation dichotomy in EU-Russia relations. Southeast European Studies and Black Sea Studies, 1-16. http://eprints.1se.ac.uk/67022/1/EU_Russia\%20relations_2016.pdf.

Croft, A. (2014, December 4). Bulgaria says it is suffering from EU sanctions on Russia. https://www.reuters.com/article/ukraine-crisis-eu-bulgaria-idUSL6N0TO3N420141204

Crozet, M., \& Hinz, J. (2020). Friendly fire: The Trade impact of the Russia sanctions and counter-sanctions. Economic Policy, 35(101), 97-146.

Cutmore, G. \& Reid, D. (2017, October 4). Sanctions on Russia don't work, says Hungary's foreign minister. $C N B C$. https://www.cnbc.com/2017/10/04/russian-sanctions-dont-worksays-hungary.html

Dębiec, K. (2019, February 10). A Crisis in the Czech Republic's relations with China and Russia. Centre for Eastern Studies.

https://www.osw.waw.pl/en/publikacje/analyses/2019-10-02/a-crisis-czech-republicsrelations-china-and-russia

Deni, J. R. (2020, March 27). France wants a Western reset with Russia: What should that look like? Foreign Policy Research Institute. https://www.fpri.org/article/2020/03/francewants-a-western-reset-with-russia-what-should-that-look-like/

Dunaev, A.(2018, March 5).Why Spain Doesn't Fear the Russian Threat. Carnegie Moscow Center, https://carnegie.ru/commentary/75698

DW News (2014, June 24). Austria defies US, EU over South Stream during Putin visit. https://www.dw.com/en/austria-defies-us-eu-over-south-stream-during-putin-visit/a$\underline{17734602}$

European Parliment. (2020, September). The geopolitical implications of the COVID-19 pandemic. Policy Department for External Relations :Directorate General for External Policies of the Union.

https://www.europarl.europa.eu/RegData/etudes/STUD/2020/603511/EXPO_STU(2020) 603511_EN.pdf.

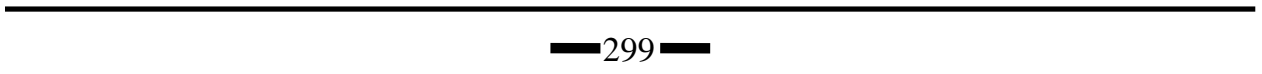




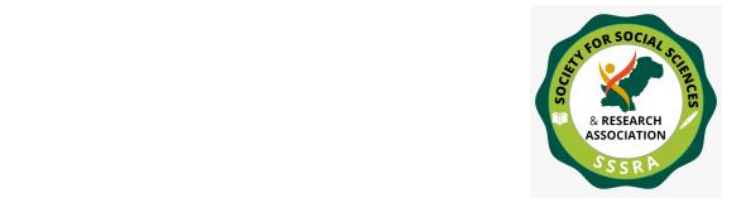

Export.gov. (2019, Aug, 14). Russia - Sanctions: Overview of United States sanctions on Russian persons (individuals, entities, and vessels) https://www.export.gov/article?series=a0pt0000000PAulAAG\&type=Country_Commerc ial kav

Facon, I. (2018). Russia and the European great powers. In EU-Russia Relations in Crisis: Understanding Diverging Perceptions. 167-183. Routledge.

Forbrig, J. (2015). A Regional Disunited? Central European Response to the Russia-Ukraine Crisis. European Policy Paper 1. pp22

Francis, D. (2021, January 2). US imposes new sanctions to kill off Putin's pet pipeline. Atlantic Council. https://www.atlanticcouncil.org/blogs/ukrainealert/us-imposes-newsanctions-to-kill-off-putins-pet-pipeline/

Gazprom Export. (2021). Foreign Partner: Austria. http://www.gazpromexport.ru/en/partners/

Gressel, G. (2015, January 21). How should Europe respond to Russia? The Austrian view. https://ecfr.eu/article/commentary_how_should_europe_respond_to_russia_the_austrian_ view405/

Gugarats, H. (2021, January 1). US Congress authorizes new Nord Stream 2 sanctions. Argusmedia. https://www.argusmedia.com/en/news/2173670-us-congress-authorizesnew-nord-stream-2-sanctions

Heng, C. (2020, July 9). France and Russia benefit from special relationship. Global Times. https://www.globaltimes.cn/content/1194080.shtml.

Holroyd, M. (2021, March 3). Slovakia's prime minister steps down amid Sputnik V vaccine scandal. Euro News. https://www.euronews.com/2021/03/28/slovakia-s-prime-ministerto-step-down-amid-sputnik-v-vaccine-scandal

International Investment Bank (2017, November 23). Czech Presidents' visit to Russia: IIB Partakes in A Dialogue Between Businessmen From Both Countries, https://iib.int/en/articles/vizit-prezidenta-chehii-v-rossiyu-mib-uchastvuet-v-dialogebiznesmenov-dvuh-stran

Isachenkov, V. (2018, October 24). Russian, Italy vow to expand ties despite EU sanctions. https://apnews.com/article/64e375f7a3ef45769a32848eb3be3b69

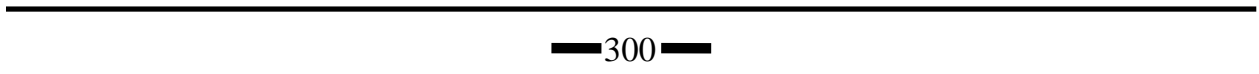




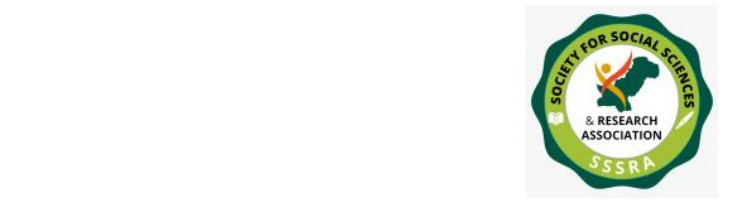

Pak. Journal of Int'L Affairs, Vol 4, Issue 3 (2021)

Crimean Annexation: EU Sanctions ...

Kapoor, N. (2021, March 11). Russia-EU Relations: The End of a Strategic Partnership.

Observe Research Foundation. https://www.orfonline.org/research/russia-eu-relationsthe-end-of-a-strategic-partnership/

Kapoor, N. (2021, March 11). Russia-EU Relations: The End of a Strategic Partnership. Observer Research Foundation. https://www.orfonline.org/research/russia-eu-relationsthe-end-of-a-strategic-partnership/

Kastoueva-Jean, T. (2019, December 9). Is a 'Reset' Between France and Russia Needed and, If So, Is It Possible? French Institute of International Studies. https://www.ifri.org/en/publications/publications-ifri/articles-ifri/reset-between-franceand-russia-needed-and-if-so-it

Larsen, H. B. L. (2021, June 8). Why NATO should not offer Ukraine and Georgia membership action plans. War On The Rock. https://warontherocks.com/2021/06/whynato-should-not-offer-ukraine-and-georgia-membership-action-plans

Lessenski, M. (2015). Bulgaria: Increasingly Assertive but not Hawkish. In J. Forbrig (Ed.), A Region Disunited?: Central European Responses to the Russia-Ukraine Crisis (pp. 7-11). German Marshall Fund of the United States. http://www.jstor.org/stable/resrep19010.5

Lewis, B. \& Santa, M. (2014, July 31). EU adopts toughest Russian sanctions yet, targets five Russian banks. Reuters https://www.reuters.com/article/us-ukraine-crisis-euidUSKBN0G01SD20140731.

Lords, H. O. (2015) The EU and Russia: before and beyond the Crisis in Ukraine. London: House of Lords. p.58

Maio, G. De. (2019, March 11). Italy and Russia, the link is increasingly close, Reset Dialogues. https://www.resetdoc.org/story/italy-russia-link-increasingly-close/

Oligie, C. N. (2019). Why Russia is involved in the Syrian Civil War: One Issue, Many Views. Acta Universitatis Danubius. Relationes Internationales, 12(1), 93-136.

Otskivi, M (2016) The Possible Russian threat towards the Baltic states and NATO's role in it. [Bachelor's thesis] Tallinn Allinn University of Technology, School of Economics and Business Administration International Relations Institute, digikogu.taltech.ee.

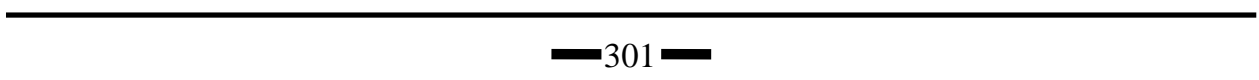




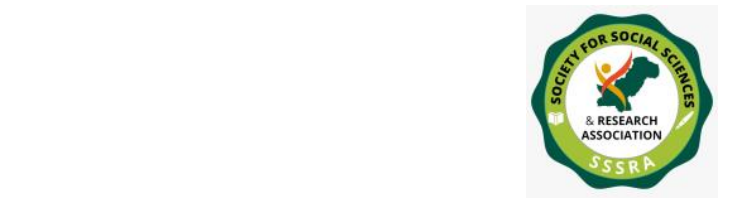

Oxenstierna, S., \& Olsson, P. (2015). The Economic Sanctions Against Russia: Impact and prospects of success. Försvarsanalys, Totalförsvarets forskningsinstitut (FOI).

Portela, C., Pospieszna, P., Skrzypczyńska J. \&Walentek, D. (2020, Aug 10). Consensus against all odds: explaining the persistence of EU sanctions on Russia. Journal of European Integration, 30 (3). 344-366. https://www.tandfonline.com/doi/full/10.1080/07036337.2020.1803854.

Portela, C., Pospieszna, P., Skrzypczyńska, J., \& Walentek, D. (2020). Consensus against all odds: explaining the persistence of EU sanctions on Russia. Journal of European Integration, 1-17. https://www.tandfonline.com/doi/pdf/10.1080/07036337.2020.1803854?needAccess=true

President of Russia (2017, November 21a). Vladimir Putin will meet with President of the Czech Republic Milos Zeman on November 21. http://en.kremlin.ru/events/president/news/56132

President of Russia (2017, November 21b). Vladimir Putin and Milos Zeman made press statements following Russian-Czech talks. Press Statement. http://www.en.kremlin.ru/events/president/transcripts/56140/print

Radio Free Europe and Radio Free Library. (2018, June 6). Italy's New Prime Minister Calls For Ending Some EU Sanctions On Russia. https://www.rferl.org/a/italy-new-primeminister-conte-calls-end-some-eu-sanctions-russia-stop-illegal-immigration$\underline{29274541 . \mathrm{html}}$

Radio Free Europe and Radio Free Library. (2019, November 28). Macron Says Russia, China Not NATO Allies' Common Enemies -- Terrorism Is. https://www.rferl.org/a/macron-says-russia-china-not-nato-allies-common-enemies--terrorism-is/30297520.html

Radio Free Europe: Radio Liberty. (2020, June 18). EU Extends Crimea Sanctions By One More Year. https://www.rferl.org/a/eu-extends-crimea-sanctions-by-oneyear/30678063.html.

Republic of Bulgaria: Ministry of Tourism. (2019, March 4). Bulgaria and Russia sign a twoyear joint action program in tourism. https://www.tourism.government.bg/en/kategorii/novini/bulgaria-and-russia-sign-twoyear-joint-action-program-tourism

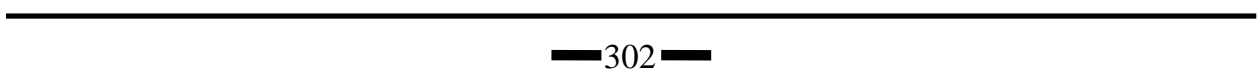




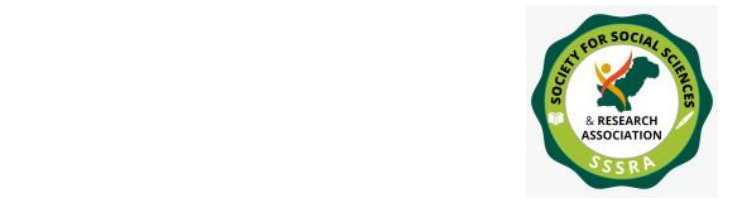

Pak. Journal of Int'L Affairs, Vol 4, Issue 3 (2021)

Crimean Annexation: EU Sanctions ...

Reuters (2014, June 21). Baltic states to back further Russia sanctions if Ukraine crisis does not ease. https://www.reuters.com/article/us-ukraine-crisis-sanctions-balticsidUSKBN0EW0H120140621

Reuters (2020, January 5). Russia begins TurkStream gas flows to Greece, North Macedonia. https://www.reuters.com/article/us-russia-bulgaria-gas/russian-begins-turkstream-gasflows-to-greece-north-macedonia-idUSKBN1Z40D0.

Romanowska, A. (2018, September 24). V4 countries towards Russian aggression against Ukraine. WARSAW Institute. https://warsawinstitute.org/v4-countries-towards-russianaggression-ukraine/.

Russell, M. (2020 March). Energy Security In The Eu's External Policy. European Parliamentary :Research Service. Brussels, European Union. https://www.europarl.europa.eu/cmsdata/210517/EPRS_IDA(2020)649334_EN.pdf

Shin, F. (2021, January 21). Sanctions by the Numbers: Spotlight on Russia. Center for a New American Society. https://www.cnas.org/publications/reports/sanctions-by-the-numbers$\underline{\text { rus }}$

Smilov, D. \& Andreev, A. (2018, May 31). Bulgaria torn between Russia and the West. DW: News and Current Affairs. https://www.dw.com/en/bulgaria-torn-between-russia-and-thewest/a-44027331

Stronski, P. (2021, June 28). A Difficult Balancing Act: Russia's Role in the Eastern Mediterranean. Carnegie Endowment For International Peace. https://carnegieendowment.org/2021/06/28/difficult-balancing-act-russia-s-role-ineastern-mediterranean-pub-84847

The Kremlin Moscow. (2014, March 18). Address by President of the Russian Federation. President of Russia. http://en.kremlin.ru/events/president/news/20603.

The Observatory of Economic Complexity (OEC) (2019). Export from Russia to Pland. https://oec.world/en/profile/bilateral-country/rus/partner/pol.

The Polish Institute of International Affairs. (2019, September 18). Slovakia's Pursuit of Better Better Relations with Russia. Bulletin No. 131. https://pism.pl/publications/Slovakias_Pursuit_of_Better_Relations_with_Russia

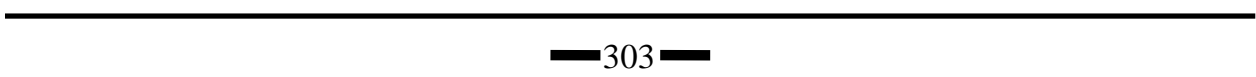




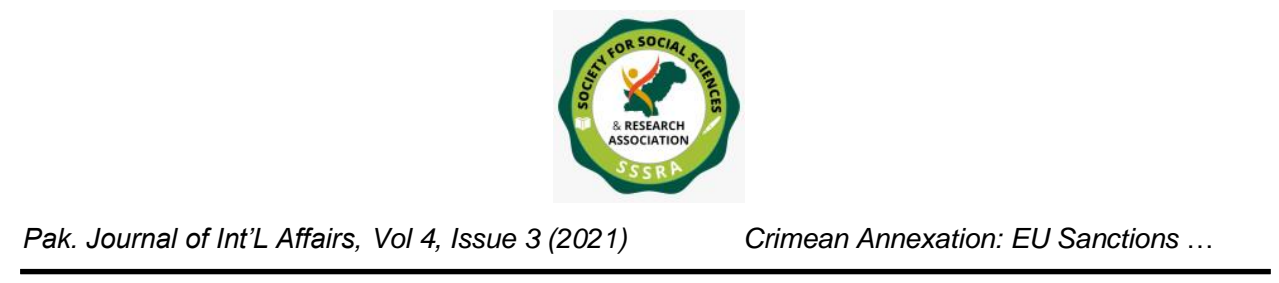

Torre, I. La. (2019) The Baltic's response to Russia's Threat: How Estonia, Latvia and Lithuania reacted to the recent actions of the Russian federation. European Army Interoperability Center. http://finabel.org/wp-content/uploads/2019/02/TheBaltic\%E2\%80\%99s-response-to-Russia\%E2\%80\%99s-Threat-W.pdf

Tsolova, T. \& Soldatkin, V. (2019, October 21). Russia says Bulgaria to complete pipeline stretch of TurkStream by 2020. Reuters. https://www.reuters.com/article/us-bulgaria-gasturkstream-idUSKBN1X01F8.

Ulatowski, R. (2020). Energy Policy in the Context of the EU's Eastern Policy. In Ambiguities of Europe's Eastern Neighbourhood. (pp. 93-107). Springer VS, Wiesbaden.

United Nation General Assembly (2014, April 1). Resolution adopted by the General Assembly on 27 March 2014,68/262: Territorial integrity of Ukraine, https://www.securitycouncilreport.org/atf/cf/\%7B65BFCF9B-6D27-4E9C-8CD3CF6E4FF96FF9\%7D/a_res_68_262.pdf.

Veebel, V., \& Markus, R. (2016). At the dawn of a new era of sanctions: Russian-Ukrainian crisis and sanctions. Orbis, 60(1), 128-139.

Wallberg, S. (2015). What is behind the lack of unity on the EU sanctions towards Russia?. Department of Political Science: Lund University. https://www.freit.org/WorkingPapers/Papers/Other/FREIT979.pdf

Wang, W. (2015). Impact of western sanctions on Russia in the Ukraine crisis. Journal of Politics and Law. (8), 2. Canadian Center of Science and Education.

Zafar, S. S. (2015). A Comparative Study Of Us-European Union Policies Towards The Middle Eastern, Balkans And South Asian Crises (1990-2002) (Doctoral dissertation, University of Karachi).

Zafar, S. S. (2015). The Ukraine Crisis and the EU. Journal of European Studies, 31(2).

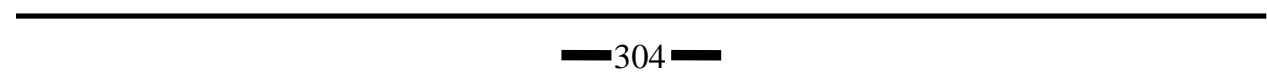

